\title{
Spatial and Temporal Variations in the Geochemistry of the Brahmaputra River Water
}

\author{
Sumi Handique ${ }^{1 *}$, Pragyan Sharma1, Kushal K. Baruah¹, Jayant K. Tripathi ${ }^{2}$ \\ ${ }^{1}$ Department of Environmental Science, Tezpur University, Tezpur, India \\ ${ }^{2}$ School of Environmental Sciences, Jawaharlal Nehru University, New Delhi, India \\ Email: *sumihandique@gmail.com
}

How to cite this paper: Handique, S., Sharma, P., Baruah, K.K. and Tripathi, J.K. (2017) Study on the Spatial and Temporal Variations in the Geochemistry of the Brahmaputra River Water. International Journal of Geosciences, 8, 756-765.

https://doi.org/10.4236/ijg.2017.85042

Received: December 24, 2014

Accepted: May 28, 2017

Published: May 31, 2017

Copyright $\odot 2017$ by authors and Scientific Research Publishing Inc. This work is licensed under the Creative Commons Attribution International License (CC BY 4.0).

http://creativecommons.org/licenses/by/4.0/

\begin{abstract}
Spatial and temporal variation in the major ion composition of the waters in the Brahmaputra River has been measured to understand chemical weathering and the factors controlling these processes. Samples were collected from the Brahmaputra mainstream at five stations Pasighat, Dibrugarh, Tezpur, Guwahati and Dhubri during monsoon and post monsoon seasons. The total dissolved solids in the waters of the Brahmaputra system ranges between 62.5 and 192.5 $\mathrm{mgl}^{-1}$. The (Total dissolved solids) TDS of the Brahmaputra measured in this study are less than the values reported by earlier workers. Gibbs plot was plotted to investigate the dominant process controlling the water chemistry of the Brahmaputra. The plots of TDS vs. $(\mathrm{Na}+\mathrm{K}) /(\mathrm{Ca}+\mathrm{Na}+\mathrm{K})$ and TDS vs. $\mathrm{Cl} / \mathrm{Cl}+\mathrm{HCO}_{3}^{-}$indicate that rock weathering is the main process controlling the chemistry of water in the Brahmaputra River. Factor analysis was done to study the factors controlling the water chemistry of the Brahmaputra.
\end{abstract}

\section{Keywords}

Spatial, Temporal, Weathering, TDS, Brahmaputra

\section{Introduction}

The Brahmaputra is one of the world's largest rivers, with drainage area of 580,000 sq. km. (50.5\% in China, 33.6\% in India, $8.1 \%$ in Bangladesh and 7.8\% in Bhutan). In India, its basin is shared by Arunachal Pradesh (41.9\%), Assam (36.3\%), Meghalaya (6.1\%), Nagaland (5.6\%), Sikkim (3.8\%) and West Bengal (6.3\%). It is a unique river which drains such diverse environments as the cold dry plateau of Tibet, the rain-drenched Himalayan slopes, the landlocked alluvial plains of Assam and the vast deltaic lowlands of Bangladesh. The Brahmaputra, one of the major river systems of the world, is characterized by very high rates of basin erosion, sediment yield, and channel change [1]. The river carries an aver- 
age annual suspended load of 400 million metric tons at Pandu at an average daily rate of nearly two million metric tons in rainy season (May to October) accounting for more than $95 \%$ of annual suspended load [1]. Transport rates as high as 26 million metric tons are recorded during peak flood flows. An extremely dominant monsoon interacting with a unique physiographic setting, fragile geological base and active seismo-tectonic instability together with anthropogenic factors have moulded the Brahmaputra into one of the world's most intriguing gigantic fluvial systems [1] [2].

In this study we tried to find spatial and temporal variation in the major ion composition of the waters in the Brahmaputra River to understand water geochemistry, chemical weathering and the factors controlling these processes.

\section{Materials and Methods}

\subsection{Study Area}

The Brahmaputra drains the Tibetan Plateau of China and is dominated by upland tributaries originating in the Himalayas. The Brahmaputra flows through various rock types including Precambrian metamorphics (high-grade schists, gneisses, quartzites, and metamorphosed limestones), felsic intrusives, and $\mathrm{Pa}$ leozoic-Mesozoic sandstones, shales and limestones [3].

The drainage basin of the Brahmaputra System can be divided into five geologically and climatically different sub basins (Figure 1) [4]. These are:

1) the high plateau of Tibet;

2) the Eastern Syntaxis;

3) the Mishmi Hills or the Eastern Drainage;

4) the Himalaya Mountains;

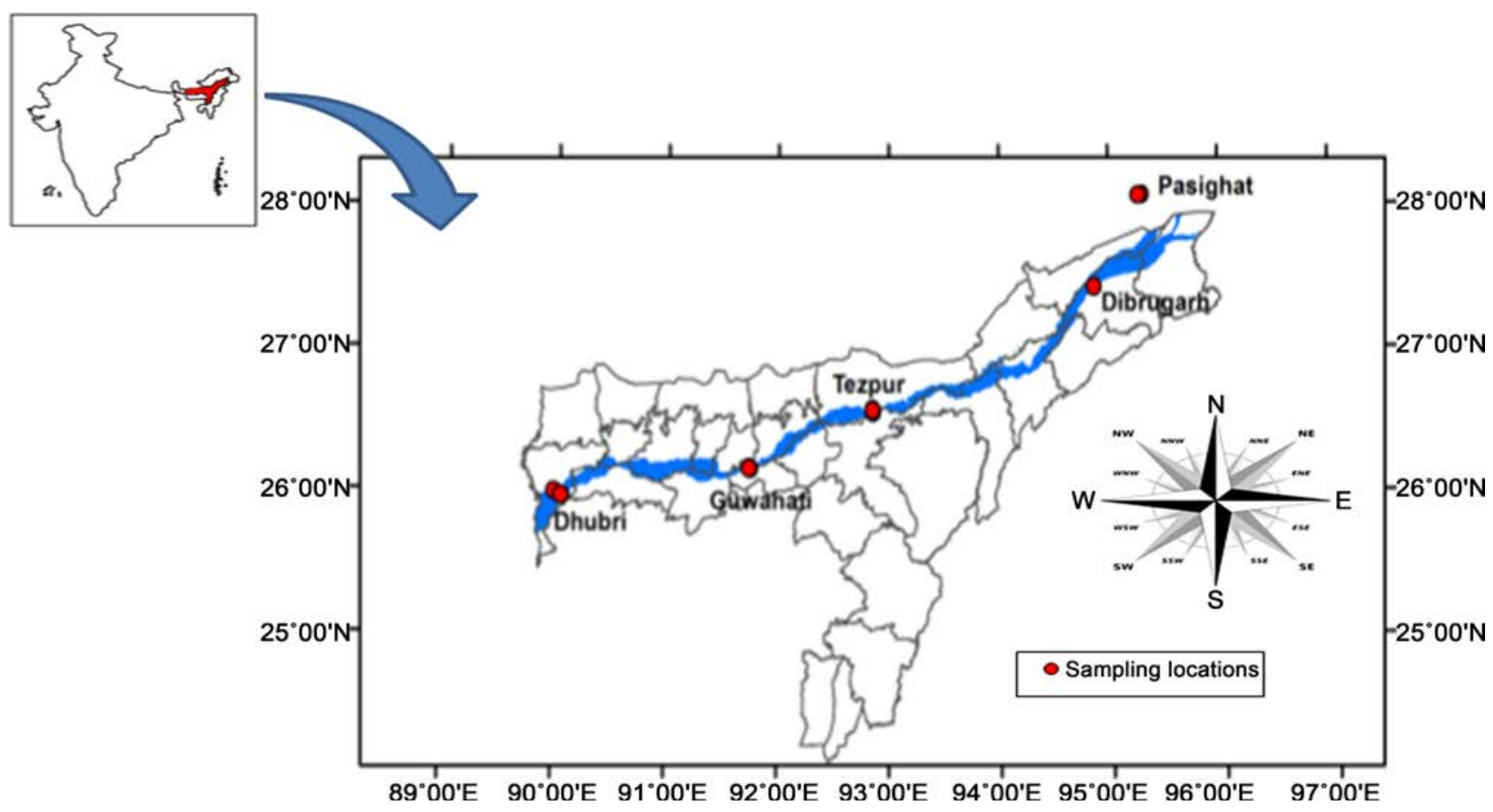

Figure 1. The sampling sites in the Brahmaputra River. 
Table 1. Sampling stations and date of sampling.

\begin{tabular}{cccc}
\hline Sampling & Coordinates & Monsoon & Post monsoon \\
\hline Pasighat & $95^{\circ} 16^{\prime} 16.79^{\prime \prime} \mathrm{E} 28^{\circ} 5^{\prime} 57.66^{\prime \prime N}$ & $31 / 07 / 2013$ & $11 / 01 / 2014$ \\
Dibrugarh & $94^{\circ} 51^{\prime} 48.18^{\prime \prime} \mathrm{E} 27^{\circ} 27^{\prime} 57.37^{\prime \prime} \mathrm{N}$ & $31 / 07 / 2013$ & $26 / 01 / 2014$ \\
Tezpur & $92^{\circ} 51^{\prime} 23.75^{\prime \prime} \mathrm{E} 26^{\circ} 36^{\prime} 14.57^{\prime \prime} \mathrm{N}$ & $31 / 07 / 2013$ & $26 / 01 / 2014$ \\
Guwahati & $91^{\circ} 44^{\prime} 36.75^{\prime \prime} \mathrm{E} 26^{\circ} 11^{\prime} 41.00^{\prime \prime} \mathrm{N}$ & $31 / 07 / 2013$ & $12 / 01 / 2014$ \\
Dhubri & $90^{\circ} 33^{\prime} 18.92^{\prime \prime} \mathrm{E} 25^{\circ} 59^{\prime} 21.72 \mathrm{~N}$ & $31 / 07 / 2013$ & $14 / 01 / 2014$ \\
\hline
\end{tabular}

5) the Indo-Myanmar and Naga-Patkoi Ranges or the Southern Drainage;

6) the plains of Assam and Bangladesh.

\subsection{Sampling}

Water samples from the Brahmaputra mainstream at five stations (Figure 1 and Table 1) were collected during two seasons: the monsoon and the post monsoon. The monsoon samples were collected during the month of July, representing peak discharge, and the post monsoon samples were collected in January. The Brahmaputra mainstream was sampled at five stations: Pasighat, Dibrugarh, Tezpur, Guwahati, and Dhubri (Figure 1 and Table 1).

Soon after their collection, two separate aliquots of $500 \mathrm{ml}$ water were filtered using $0.45 \mu \mathrm{m}$ nylon membrane Millipore filters. One of the filtered aliquots was acidified with double-distilled $\mathrm{HNO}_{3}$ for cations analysis and the other aliquot was preserved unacidified for anion measurements. In addition, one sample of $250 \mathrm{ml}$ water was collected and stored unfiltered for alkalinity measurements. Temperature and $\mathrm{pH}$ of the water samples were measured at site. The water samples were brought to the laboratory for further analysis. Alkalinity was measured by acid titration; $\mathrm{Cl}$, and $\mathrm{SO}_{4}$ by titration; $\mathrm{K}$ and $\mathrm{Na}$ by flame AAS; and $\mathrm{Al}, \mathrm{Pb}, \mathrm{Fe} \mathrm{Ca}, \mathrm{Mg}$, and $\mathrm{Si}$ using ICP-AES.

\section{Results and Discussions}

The various parameters measured are given in Table 2. It was observed that $\mathrm{pH}$ was almost same at all sites during monsoon indicating no spatial variation (may be due to dilution effect) whereas decreases downstream and was found to be least in Guwahati suggesting anthropogenic inputs (from municipal waste and Bharalu river). Mostly all parameters showed more values in monsoon except hardness which may be due to increased carbonate dissolution because of increased chemical weathering. In this study it was observed that the total dissolved solids in the waters of the Brahmaputra river ranges between 62.5 and $194.5 \mathrm{mgl}^{-1}$ (Table 2).

The TDS of the Brahmaputra measured in this study is less than the values reported by earlier workers. Table 3 compares the values from earlier studies with the present study and these results show that over two decades the TDS in the Brahmaputra have decreased which can be attributed to variations in run-off. 
Table 2. Showing different parameters (units in $\mathrm{mg} / \mathrm{l}$ except $\mathrm{pH}$ and EC in micro seimens).

\begin{tabular}{|c|c|c|c|c|c|c|c|c|c|c|c|c|c|c|c|c|}
\hline Place & Name & $\mathrm{pH}$ & $\mathrm{EC}$ & Alkalinity & TDS & $\mathrm{SO}_{4}^{2-}$ & Hardness & $\mathrm{Cl}^{-}$ & $\begin{array}{l}\text { Reactive } \\
\text { silica }\end{array}$ & $\mathrm{Ca}$ & $\mathrm{Fe}$ & $\mathrm{Mg}$ & $\mathrm{Na}$ & $\mathrm{K}$ & $\mathrm{Al}$ & $\mathrm{Pb}$ \\
\hline Pasighat Monsoon & PAS.M & 6.2 & 132.5 & 130.2 & 62.5 & 16.28 & 185 & 56.8 & 2.16 & 22.81 & 1.48 & 3.75 & 2.74 & 1.42 & 1.27 & 0.022 \\
\hline Pasighat Post Monsoon & PAS.PM & 7.7 & 221 & 155.4 & 102.5 & 22.21 & 100 & 63.9 & 3.79 & 27.8 & 0.09 & 5.33 & 3.49 & 2.04 & 0.46 & 0.003 \\
\hline Dibrugarh Monsoon & DIB.M & 6.2 & 97.5 & 115.4 & 47 & 6.43 & 185 & 71 & 2.4 & 13.52 & 0.23 & 2.3 & 2.17 & 2.34 & 0.38 & 0.013 \\
\hline Dibrugarh Post Monsoon & DIB.PM & 7.6 & 187 & 180.6 & 89 & 12.14 & 90 & 71 & 5.49 & 25.41 & 0.11 & 5.51 & 3.25 & 3.23 & 0.43 & 0.001 \\
\hline Tezpur Monsoon & TEZ.M & 6.1 & 134 & 180.4 & 63.5 & 11.07 & 157.5 & 60.35 & 1.24 & 4.89 & 0.22 & 0.9 & 0.96 & 1.87 & 0.64 & 0.001 \\
\hline Tezpur Post Monsoon & TEZ.PM & 7.2 & 195 & 205.4 & 90.5 & 14 & 90 & 46.15 & 4.72 & 24.6 & 0.17 & 5.43 & 3.42 & 2.65 & 0.52 & 0.002 \\
\hline Guwahati Monsoon & GHY.M & 6.1 & 130 & 205 & 63.5 & 11.14 & 185 & 67.45 & 3.27 & 18.2 & 1.91 & 3.44 & 3.03 & 2.78 & 2.15 & 0.022 \\
\hline Guwahati Post Monsoon & GHY.PM & 3.3 & 816.5 & 180 & 194.5 & 19.92 & 95 & 37.28 & 5.78 & 27.49 & 0.003 & 6.13 & 3.47 & 2.87 & 0.38 & 0.003 \\
\hline Dhubri Monsoon & DHU.M & 6.1 & 88.5 & 217.5 & 44 & 10 & 187.5 & 56.8 & 3.12 & 19.36 & 2.93 & 3.94 & 2.54 & 2.15 & 1.53 & 0.016 \\
\hline Dhubri Post Monsoon & DHU.PM & 5.4 & 212.5 & 230 & 98.5 & 14.64 & 90 & 49.2 & 3.88 & 28.29 & 0.06 & 6.78 & 3.43 & 2.82 & 0.39 & 0.001 \\
\hline Mean Monsoon & & 6.13 & 116.5 & 177.7 & 56.1 & 10.98 & 180 & 62.48 & 2.45 & 15.76 & 1.36 & 2.86 & 2.29 & 2.11 & 1.19 & 0.017 \\
\hline Mean Post Monsoon & & 5.67 & 196.06 & 171.1 & 93.44 & 12.69 & 129.8 & 54.07 & 3.26 & 19.58 & 0.81 & 3.97 & 2.63 & 2.23 & 0.83 & 0.009 \\
\hline Standard deviation monsoon & & 0.07 & 21.73 & 35.67 & 9.74 & 3.533 & 12.6 & 6.45 & 0.82 & 6.92 & 1.16 & 1.26 & 0.81 & 0.51 & 0.71 & 0.005 \\
\hline $\begin{array}{c}\text { Standard deviation } \\
\text { post monsoon }\end{array}$ & & 2.09 & 203.64 & 51.12 & 98.4 & 5.22 & 57.5 & 18.12 & 1.56 & 8.01 & 0.95 & 1.91 & 0.94 & 0.74 & 0.57 & 0.008 \\
\hline
\end{tabular}

Table 3. Decadal variation in TDS of the Brahmaputra along its course.

\begin{tabular}{|c|c|c|c|}
\hline Location & Date & TDS (mg/l) & Reference \\
\hline \multirow[t]{2}{*}{ Pasighat } & Jul-13 & 62.5 & This study \\
\hline & Jan-14 & 102.5 & This study \\
\hline \multirow[t]{4}{*}{ Dibrugarh } & Apr-82 & 107 & [5] \\
\hline & Oct-99 & 128 & {$[6]$} \\
\hline & Jul-13 & 97 & This study \\
\hline & Jan-14 & 119 & This study \\
\hline \multirow[t]{9}{*}{ Guwahati } & Jul-79 & 101 & [4] \\
\hline & Jul-00 & 112 & [7] \\
\hline & Apr-82 & 91 & [5] \\
\hline & Apr-00 & 111 & [7] \\
\hline & Dec-82 & 144 & [3] \\
\hline & Dec-00 & 164 & [7] \\
\hline & Oct-99 & 102 & {$[6]$} \\
\hline & Jul-14 & 102 & This study \\
\hline & $12-01-2014$ & 194.5 & This study \\
\hline \multirow[t]{2}{*}{ Goalpara } & Apr-82 & 92 & [5] \\
\hline & Dec-82 & 147 & [5] \\
\hline \multirow[t]{3}{*}{ Dhubri } & Jul-00 & 106 & [7] \\
\hline & Aug-13 & 64 & This study \\
\hline & Jan-14 & 98.5 & This study \\
\hline
\end{tabular}

5. Hu et al., 1982; 4. Chen and Guan, 1981; 7. Sarin et al., 1989; 8. Galy and France-Lanord, 1999; 9. Singh et al., 2005. 


\subsection{Gibbs Plot of Anions and Cations of Water Samples}

In Figure 2(a) and Figure 2(b), it is observed that the anions and cations respectively, present in the water samples are mainly due to rock water interaction for both the seasons. Evaporation has a bit influence in the post monsoon samples.

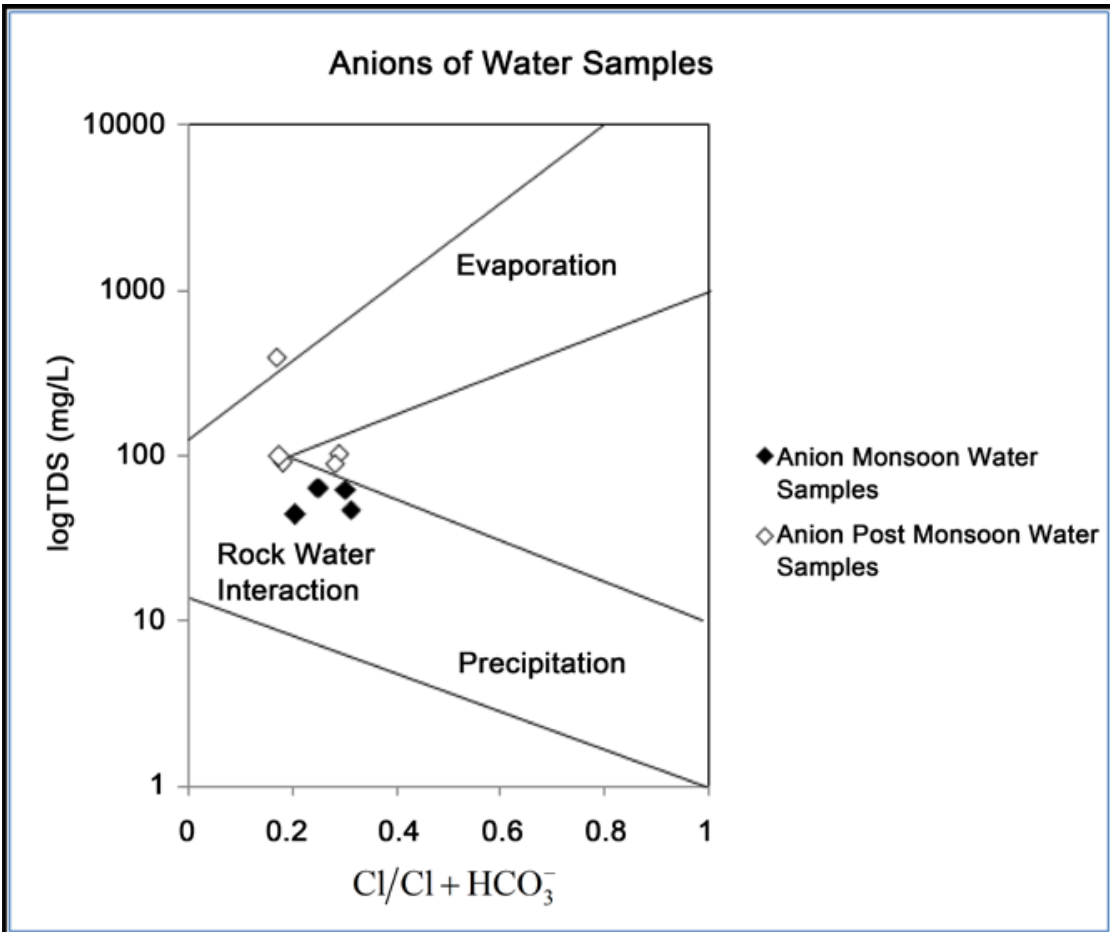

(a)

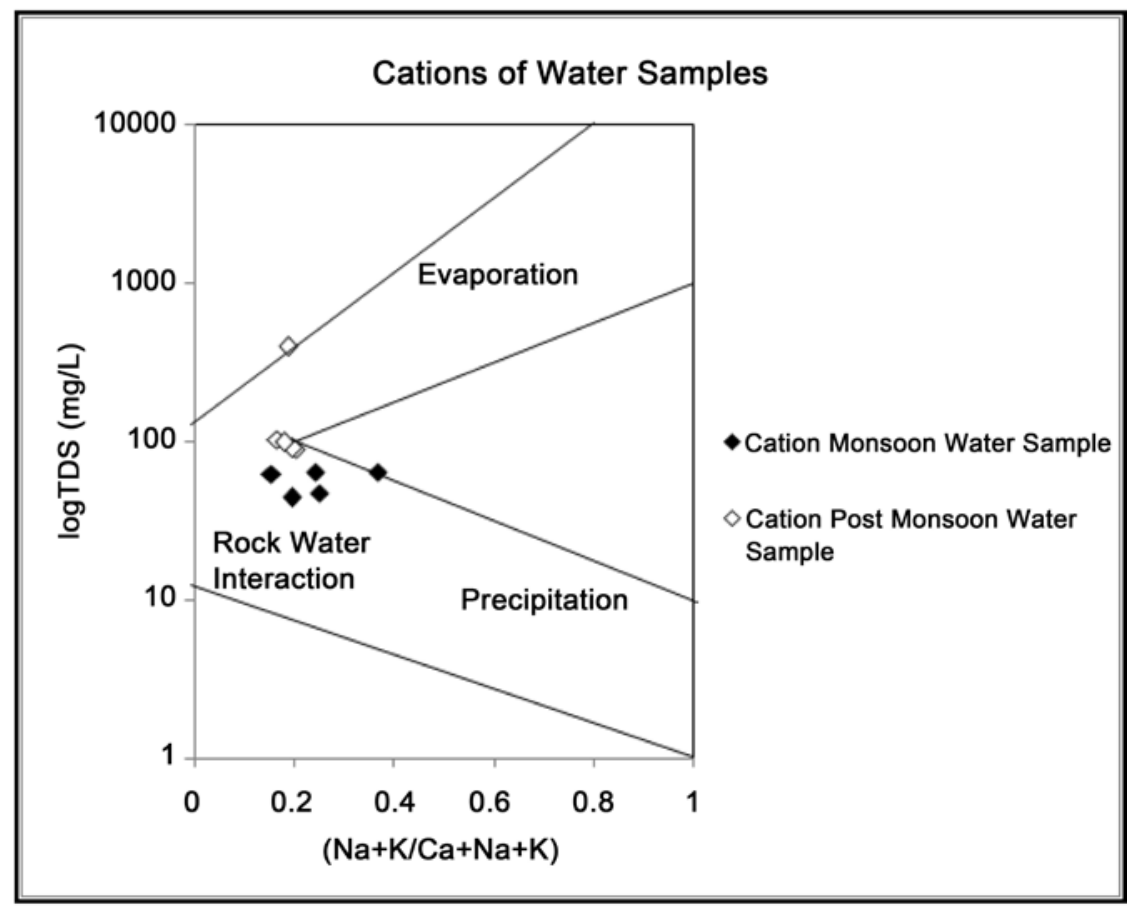

(b)

Figure 2. (a) Gibbs plot of Anions of water samples in Monsoon and Post Monsoon; (b) Gibbs plot of cations of water samples in Monsoon and Post Monsoon seasons. 


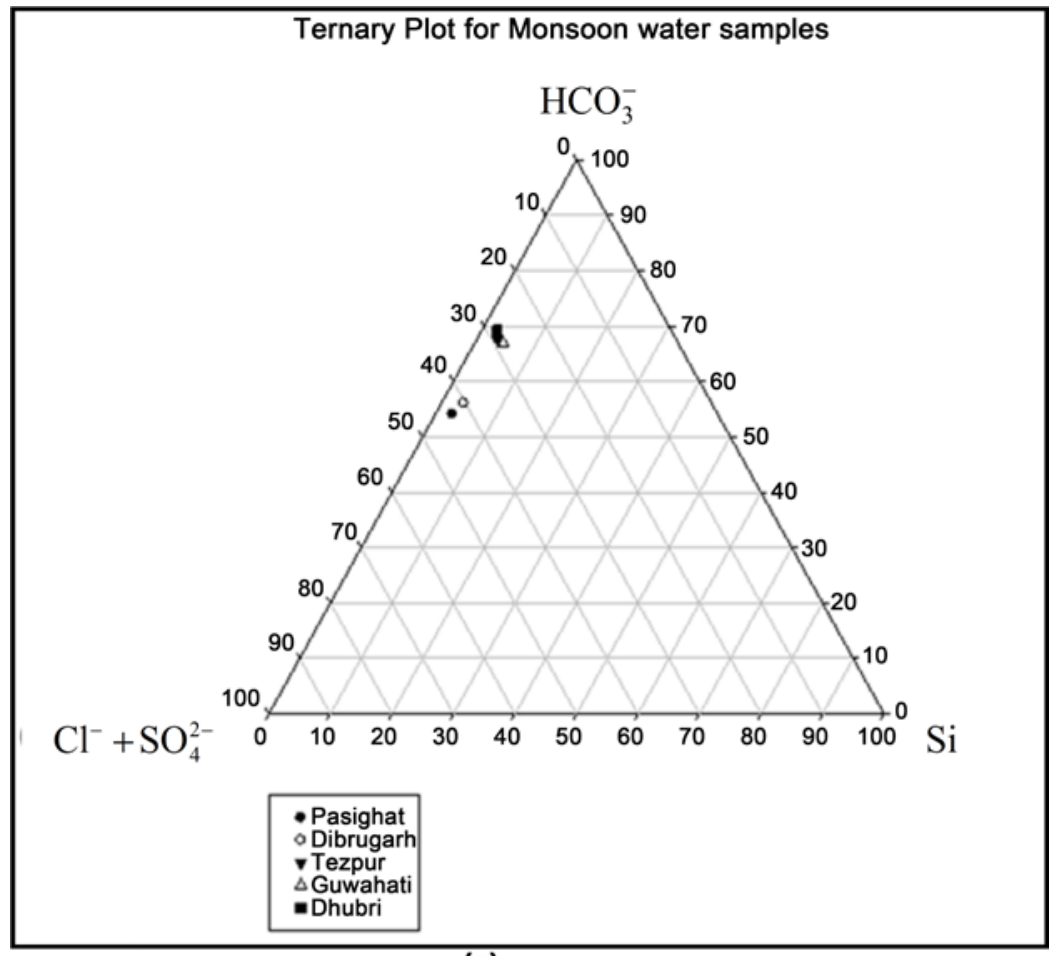

(a)

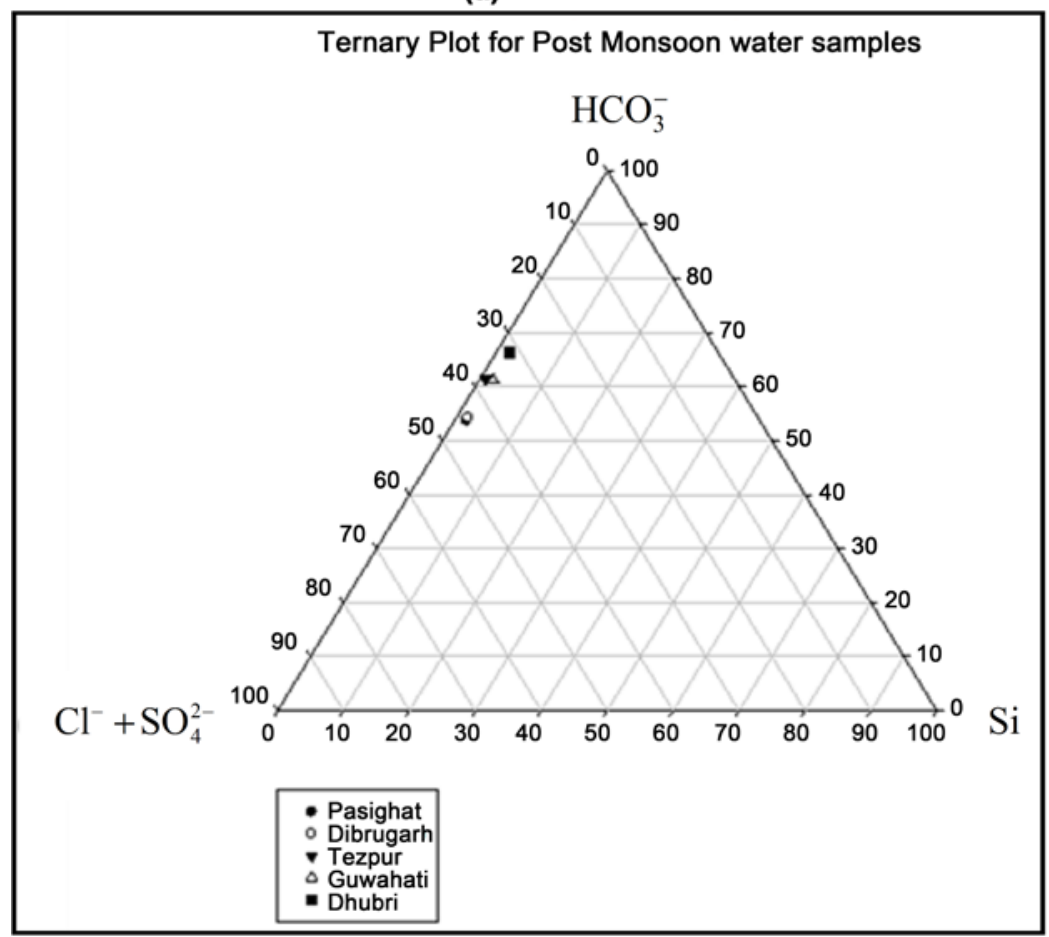

(b)

Figure 3. Ternary plot of anions water samples in (a) Monsoon and (b) Post Monsoon Season.

Gibbs plot [10] was plotted to investigate the dominant process controlling the water chemistry of the Brahmaputra. The plot of TDS vs. $(\mathrm{Na}+\mathrm{K}) /(\mathrm{Ca}+\mathrm{Na}$ $+\mathrm{K})$ and TDS vs. $\mathrm{Cl} / \mathrm{Cl}+\mathrm{HCO}_{3}^{-}$indicate that rock weathering is the main process controlling the chemistry of water in the Brahmaputra River. Higher concentration of Calcium and Bicarbonate, suggest chemical weathering of car- 
bonates is the predominant process resulting in the production of these ions. However the presence of Potassium and Sodium and other ions suggest that weathering of Silicates is also important.

\subsection{Ternary plot of Anions and Cations of Water Samples in Monsoon and Post Monsoon}

From the ternary plots (Figure 4(a) and Figure 4(b)) it was found that most of the samples fall towards the Ca apex indicating the dominance of $\mathrm{Ca}$ in the cation budget of the Brahmaputra.

On the anion plot the samples cluster towards $\mathrm{HCO}_{3}^{-}$both in monsoon as well as post monsoon seasons (Figure 3(a) and Figure 3(b)). A preliminary inference from these distributions is that a major source of dissolved cations to the water is carbonate weathering which is in accordance with the earlier study by [9].

\subsection{Factor Analysis}

Table 4(a) and Table 4(b) show the factor analysis of various parameters of water samples in Monsoon and Post monsoon seasons respectively.

From factor analysis of various parameters in monsoon and post monsoon showed 4 probable sources with most of the Sodium, Lead, Sulphate, Magnesium, Iron, Aluminum, Calcium, and Chromium coming from source 1. Lead has 3 probable sources and Silicon and Aluminum coming from the same source.

In monsoon Factor 1 explaining 46.95\% of the total variance had strong positive loadings ( $>0.80$ ) for Sodium, Lead, Sulphate, Magnesium, Iron, Aluminum, Calcium, Chromium. Factor 2 accounts for $23.8 \%$ and have strong positive loadings ( $>0.70$ ) on Potassium, Chlorine, and hardness and moderate positive loadings on $\mathrm{pH}$ and Silicon. Factor 3 accounts for $17.82 \%$ of the total variance and shows positive loadings for EC and alkalinity. Factor 4 accounts for $11.3 \%$ of the total variance.

For post monsoon 4 factors were obtained through factor analysis, Factor 1 accounted for $40.76 \%$ of the total variance and have strong positive loadings with EC, alkalinity, TDS, Sodium, Sulphate, Calcium and Chromium. Factor 2 accounts for $28.79 \%$ of the total variance, with positive loadings on Aluminum, Sulphate, Chlorine, and hardness, Lead, Sodium and TDS. Factors 3 correspond to $18.18 \%$ of the total variance and have positive loadings on Calcium, Silicon, Aluminum, Iron and hardness. Factor 4 accounts for $12.25 \%$ of the total variance and have positive loadings on Silicon, Potassium, Chlorine and hardness.

\section{Conclusion}

Spatio-temporal variation of the water chemistry of the Brahmaputra River was studied by measuring the physicochemical parameters carried out over a period of 1 year (monsoon and post-monsoon seasons). Though such studies were carried out in the past but none of the studies had recorded both monsoon and post monsoon variations within a year and some studies [9] were carried out more 
than a decade earlier. It was observed that there is a strong seasonal variability in cation and anion concentrations. The plots of TDS vs. $(\mathrm{Na}+\mathrm{K}) /(\mathrm{Ca}+\mathrm{Na}+\mathrm{K})$ and TDS vs. $\mathrm{Cl} / \mathrm{Cl}+\mathrm{HCO}_{3}^{-}$indicate that rock weathering is the main process

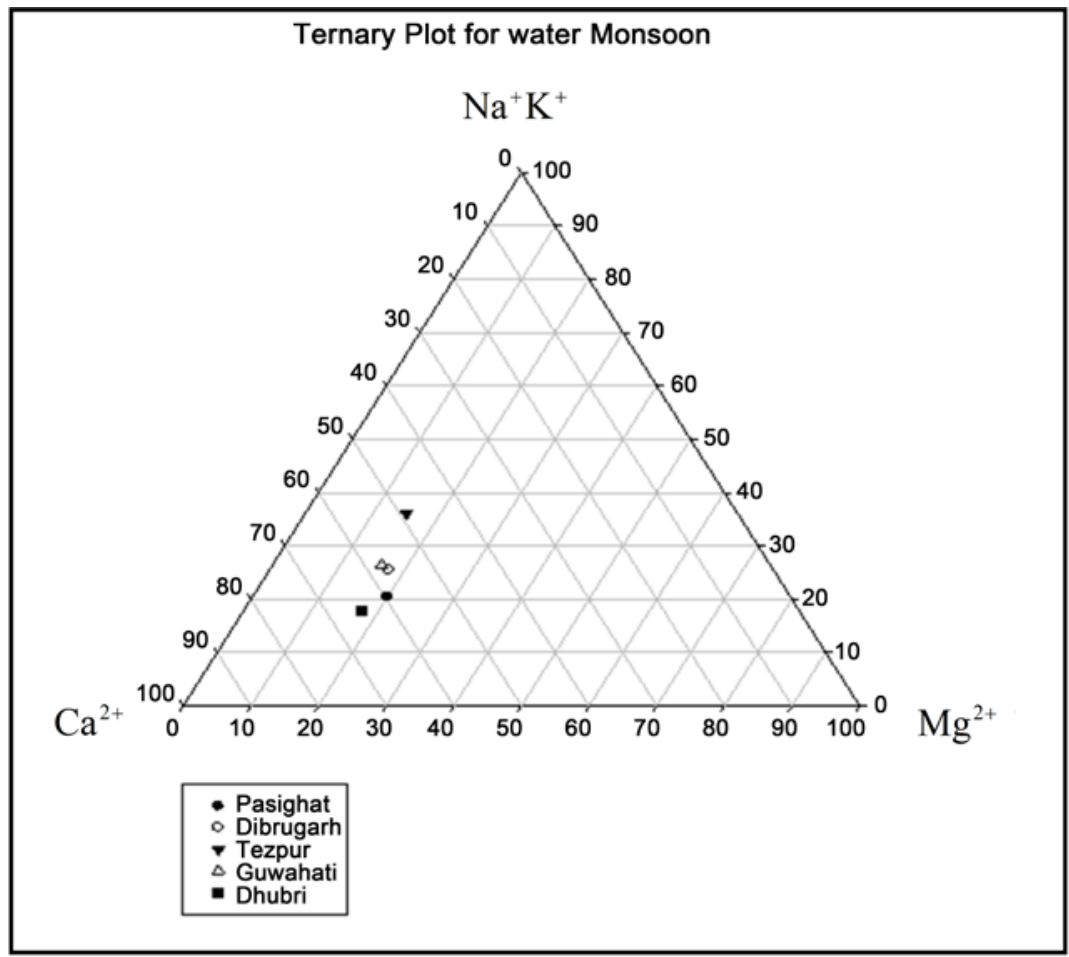

(a)

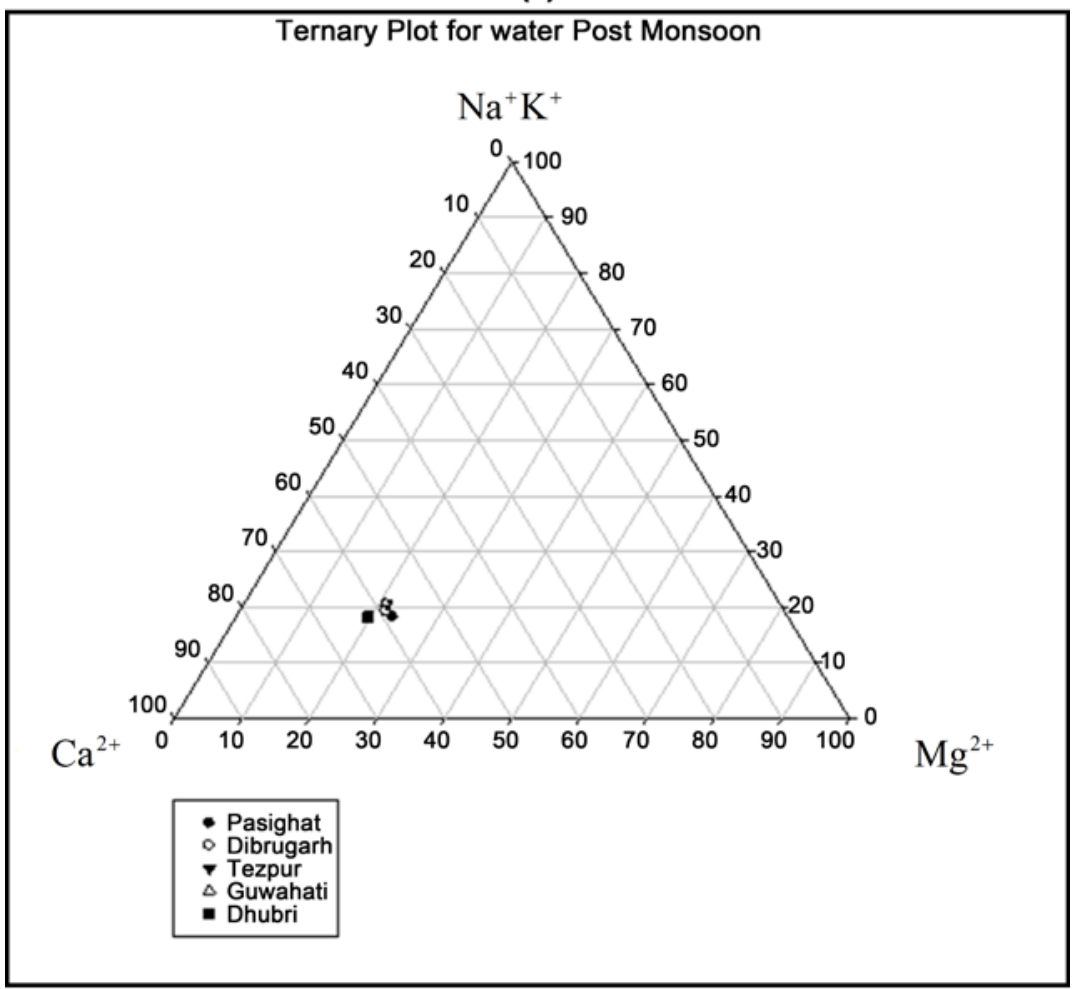

(b)

Figure 4. Ternary plot of Cations in water samples in (a) Monsoon and (b) Post Monsoon seasons. 
Table 4. (a) Factor analysis of parameters in monsoon; (b) Factor analysis of parameters in post monsoon.

(a)

\begin{tabular}{|c|c|c|c|c|}
\hline \multicolumn{5}{|c|}{ Factor analysis of the various parameters in monsoon-component matrix } \\
\hline \multicolumn{5}{|c|}{ Component } \\
\hline & 1 & 2 & 3 & 4 \\
\hline $\mathrm{Mg}$ & 0.96 & & -0.218 & -0.159 \\
\hline $\mathrm{Na}$ & 0.947 & & 0.215 & -0.286 \\
\hline $\mathrm{Ca}$ & 0.902 & -0.177 & -0.159 & -0.359 \\
\hline $\mathrm{Si}$ & 0.887 & 0.456 & & \\
\hline $\mathrm{Cr}$ & 0.881 & -0.116 & 0.399 & 0.226 \\
\hline $\mathrm{Fe}$ & 0.869 & & -0.323 & 0.373 \\
\hline $\mathrm{Pb}$ & 0.859 & -0.329 & 0.315 & -0.233 \\
\hline $\mathrm{Al}$ & 0.856 & -0.136 & 0.309 & 0.391 \\
\hline SO42- & 0.832 & 0.301 & -0.168 & -0.435 \\
\hline TDS & 0.298 & -0.95 & & \\
\hline $\mathrm{K}$ & 0.273 & 0.79 & 0.471 & 0.283 \\
\hline $\mathrm{Cl}$ & -0.155 & 0.741 & 0.572 & -0.316 \\
\hline Hardness & -0.155 & 0.741 & 0.572 & -0.316 \\
\hline EC & -0.184 & -0.7 & 0.688 & \\
\hline Alkalinity & -0.127 & -0.669 & 0.724 & 0.106 \\
\hline $\mathrm{pH}$ & 0.3 & 0.428 & & 0.852 \\
\hline$\%$ of variance & 46.957 & 23.815 & 17.829 & 11.399 \\
\hline
\end{tabular}

(b)

\begin{tabular}{|c|c|c|c|c|}
\hline \multicolumn{5}{|c|}{ Factor analysis of the various parameters in post monsoon-component matrix } \\
\hline \multicolumn{5}{|c|}{ Component } \\
\hline & 1 & 2 & 3 & 4 \\
\hline $\mathrm{EC}$ & 0.866 & -0.339 & 0.236 & 0.282 \\
\hline Alkalinity & 0.862 & -0.342 & 0.239 & 0.289 \\
\hline $\mathrm{Fe}$ & -0.805 & 0.254 & 0.403 & -0.355 \\
\hline TDS & 0.786 & 0.613 & & \\
\hline $\mathrm{Na}$ & 0.771 & 0.362 & -0.11 & -0.513 \\
\hline $\mathrm{Pb}$ & 0.77 & 0.516 & 0.375 & \\
\hline Hardness & -0.686 & 0.492 & -0.197 & 0.497 \\
\hline $\mathrm{Cl}$ & -0.686 & 0.492 & -0.197 & 0.497 \\
\hline $\mathrm{K}$ & -0.313 & -0.856 & & 0.404 \\
\hline Sulphate & 0.585 & 0.786 & & 0.197 \\
\hline $\mathrm{pH}$ & -0.235 & -0.699 & -0.32 & -0.595 \\
\hline $\mathrm{Ca}$ & 0.607 & 0.139 & -0.781 & \\
\hline $\mathrm{Cr}$ & 0.452 & -0.341 & 0.761 & -0.317 \\
\hline $\mathrm{Mg}$ & 0.312 & -0.648 & -0.667 & -0.196 \\
\hline $\mathrm{Si}$ & 0.142 & -0.54 & 0.598 & 0.575 \\
\hline $\mathrm{Al}$ & -0.489 & 0.476 & 0.579 & -0.446 \\
\hline$\%$ of variance & 40.764 & 28.79 & 18.189 & 12.258 \\
\hline
\end{tabular}


controlling the chemistry of water in the Brahmaputra River. Higher concentration of Calcium and Bicarbonate suggest chemical weathering of carbonates is the predominant process resulting in the production of these ions. From the ternary plot it was found that most of the samples fall towards the $\mathrm{Ca}$ apex indicating the dominance of $\mathrm{Ca}$ in the cation budget of the Brahmaputra. On the anion plot the samples cluster towards $\mathrm{HCO}_{3}^{-}$. A preliminary inference from these distributions is that a major source of dissolved cations to the water is carbonate weathering which is in accordance with the earlier study by [9].

\section{Acknowledgements}

The authors are thankful to the staff of Department of Environmental Science, Tezpur University for helping in carrying out all the analysis.

\section{References}

[1] Chen, C. and Guan Z. (1981) Hydrochemistry of Rivers in Xizang. In: Geological and Ecological Studies of Qinghai-Xizang Plateau, Gordon and Brach Science Publishers, New York, 1687-1692.

[2] Goswami, D.C. (1985) Brahmaputra River, Assam, India: Physiography, Basin denudation, and Channel Aggradation. Water Resource Research, 21, 959-978.

https://doi.org/10.1029/WR021i007p00959

[3] Galy, A. and France-Lanord, C. (1999) Weathering Processes in the Ganges-Brahmaputra Basin and the Riverine Alkalinity Budget. Chemical Geology, 159, 31-60.

[4] Gibbs, R.J. (1970) Mechanisms Controlling World Water Chemistry. Science, 170, 1088-1090. https://doi.org/10.1126/science.170.3962.1088

[5] Hu, M., Stallard, R.F. and Edmond, J. (1982) Major Ion Chemistry of Some Large Chinese Rivers. Nature, 298, 550-553. https://doi.org/10.1038/298550a0

[6] Ives, J.D. and Messerli, B. (1989) The Himalayan Dilemma: Reconciling development and Conservation. Routledge, .London and New York, $324 \mathrm{p}$.

https://doi.org/10.4324/9780203169193

[7] Sarin, M.M., Krishnaswami, S., Dilli, K., Somayajulu, B.L.K. and Moore, W.S. (1989) Major Ion Chemistry of the Ganga-Brahmaputra River System: Weathering Processes and Fluxes to the Bay of Bengal. Geochimica et Cosmochimica Acta, 53, 997-1009.

[8] Galy, A. and France-Lanord, C. (1999) Weathering Processes in the Ganges-Brahmaputra Basin and the Riverine Alkalinity Budget. Chemical Geology, 159, 31-60

[9] Singh, S.K., Sarin, M.M. and France-Lanord, C. (2005) Chemical Erosion in the Eastern Himalaya: Major Ion Composition of the Brahmaputra and $813 \mathrm{C}$ of Dissolved Inorganic Carbon. Geochimica et Cosmochimica Acta, 69, 3573-3588.

[10] Gibbs, R.J. (1970) Mechanisms Controlling World Water Chemistry. Science, 170, 1088-1 090 . 
Submit or recommend next manuscript to SCIRP and we will provide best service for you:

Accepting pre-submission inquiries through Email, Facebook, LinkedIn, Twitter, etc. A wide selection of journals (inclusive of 9 subjects, more than 200 journals)

Providing 24-hour high-quality service

User-friendly online submission system

Fair and swift peer-review system

Efficient typesetting and proofreading procedure

Display of the result of downloads and visits, as well as the number of cited articles Maximum dissemination of your research work

Submit your manuscript at: http://papersubmission.scirp.org/

Or contact ijg@scirp.org 